\title{
THE IMPACT OF OPENING UP A TRADITIONAL CULTURE TO TOURISM DEVELOPMENT STUDY CASE: BADUY TRIBE
}

\author{
Caecelia, Utami Umarjadi, \\ Nila K. Hidayat \\ Swiss German University, Tangerang, Indonesia
}

The Baduy Tribe is a cultured and friendly indigenous people living harmoniously in the middle of natural environment and far from the civilization. This study aims to determine the level of acceptance of opening up the Inner Baduy as a tourism destination and also to identify the impacts on the opening up the Inner Baduy to tourism development. This study use both quantitative and qualitative analysis.

The result revealed that there are three elements are used to justify the level of acceptance of the Baduy people; two showed rejections (needs and desires and opinions on opening up the Inner Baduy). This is strengthened by the result of the interviews that tribe rules and regulations do not allow the Inner Baduy to be opened up. Another finding is proven by the disadvantages that impact the host community if the Inner Baduy is opened up to tourism market. It could cause culture acculturation, a deterioration of morality, environmental damages, and also the decreased quality of local people's language. For the regional development, the opening up of the Inner Baduy can bring advantages such as improvements of infrastructures and economic benefits. The Inner Baduy is unofficially opened for visits from the tourists but the policy to open it up to mass market depends entirely on the decision of the host community.

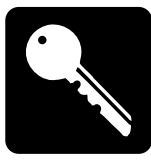

Baduy Tribe, level of acceptance, Inner Baduy, tourism destination, traditional culture 


\section{INTRODUCTION}

$\mathrm{T}$ ourism is an important industry that is interdependent with other industries. Tourism is strongly associated with culture and tradition, the environment and way of life of the host community. Business, leisure, visiting friends and relatives are activities that drive people to travel in order to fulfil their purposes. It is acknowledged that tourism impacts on aspects of all countries. Economically and politically, it creates work opportunities, stimulates investments, and establishes new networks across the globe. Environment, culture and tradition - which are the principal reasons why people visit places - are the other aspects affected, for better or worse, through tourism. Indonesia as a tourism destination has lots to offer because it has beautiful and variable nature as well as a unique culture, tradition and way of life some of which are stil untouched by outside world. One example within Indonesia is the indigenous Baduy Tribe in Banten. The Baduy Tribe is a unique ethnic group who lives in 57 villages in the south of Leuwidamar sub district, Lebak Regency, Banten Province, Indonesia. The Baduy Tribe is grouped into two clusters, the Outer Tribe and the Inner Tribe. They have their own strict distinctive traditional culture and a practice way of living that has been handed down for generations, living in harmony with nature.

The Outer Tribe is accessible to outside visitors and moderately open to modern culture. However, the most unique part of this tribe that is so interesting to see and learn from is the Inner Baduy tribe. This tribe cluster has been a closed society to outsiders for generation, and live in the midst of the forest away from modern life and it protects their heritage from the influence of modern culture.

The purpose of this study is to determine the acceptance level of Baduy people on the opening up the Inner Baduy in supporting the regional development of tourism. Beside that it is also to identify the possibility to open up the Inner Baduy to tourism market and ist development.

\section{LITERATURE REVIEW II.I. TOURISM}

There are many ways of tourism principles to be defined. Basically tourism is a discretionary activity of people to fulfill their certain travel purposes to certain destinations.

According to Pierre L. Van den Berghe (1994), "the simplest definition of tourism is traveling for pleasure". Further he emphasized, "Tourism inescapably involves contact between groups of people who might otherwise not meet, and who differ on one or more dimensions of social class, religion, language, ethnicity, or race. Tourism thus, must be seen as a special form of culture contact, of race and ethnic relations, and of class relations." (Khan/ Olsen/Var 1994, p. 619)

Basic distinctions of tourism relates to the purposes of visits, James G. Carrier (2010), "Tourism is inextricably linked with culture in many ways, including the relationship between countries providing the tourists, and the destination 'host' countries and also the interaction between the tourists and the indigenous population of the tourism destination." (Carrier 2010, p.2). Hollinshead (1994) described, as the world's travelling population becomes 
more pluralistic, so too does market for tourist activities and travel pursuit (Fitzgibbon 1987). New, emergent and non-traditional consumer segments manifest themselves and hunt for novel locations as traditional draw card areas are used up. In Tourism in the twentieth century, there has been a considerable increase not only in recreational tourism, but in the number of forms of tourism that involve substantial degree of contact with a given host population. (Khan/ Olsen/Var, 1994). Three of the six types of tourism that are related to the topic of this paper are explained as following:

(1) Cultural Tourism, Cultural Tourism defines a travel purpose of participating in the "vanishing lifestyle that lies within human memory (1984:4).

This 'peasant culture' is characterized by the pictures of local color with old style houses and other products made in traditional ways. Typical destination activities would include folklore performances and festivals. The cultural tourism definition is fundamentally based and supported by concepts of culture. Culture itself is defined "The totality of socially transmitted behavior patterns, arts, belief, institutions, and all other products of human work and thought that are characteristics of the destination population." (Goeldnerand Richie 2006, p.580). (2) Ethnic Tourism. Ethnic Tourism defines a travel purpose of experiencing and observing the cultural expressions and lifestyles of truly exotic indigenous people. Typical destination activities would include visiting native homes, attending dances and ceremonies, and possibly participating in religious rituals (Smith, 2009). According to Jafari (2003), ethnic tourism is a form of special interest as different from general tourism which focuses directly on the local people. It involves intimate contacts with the "authentic" indigenous ethnic. (3) Environmental Tourism. "Environmental Tourism is 'often ancillary to ethnic tourism'. Therefore it incorporates, with nature based tourism, indigenous tourism involving host communities. Activities include tours to wine farms, whale-watching, safari drives and camping. Cultural activities include sampling traditional foods, watching traditional dances and ceremonies and shopping for crafts." (Goeldner \& Ritchie 2009, p. 79)

\section{II.II. HERITAGE}

The term heritage comprehensively related with the term inheritance; something descended from the former generation. Heritage itself has the role of carrying historical values from the past. Hence, heritage is seen as part of the cultural tradition of a society. (Wiendu, 2009)

A more technocratic approach was suggested by Prentice (1993, p.36) that "essentially in tourism, the term 'heritage' has come to mean not only landscapes, natural history, buildings, artifacts, cultural traditions and the like which are literally or metaphorically passed on from one generation to the other, but those among these things which can be portrayed for promotion as tourism products." (Leslie \& Sigala 2005, p.8)

According to UNESCO document of "Recommendation Concerning Protection at National Level, of the Cultural and Natural Heritage" adopted in 1972, there are three types of heritage that form the basis for the development of community tourist attractions: 


\section{Natural Heritage}

Natural heritage is defined as a natural environment largely untouched by human activity. Beautiful scenery, caves, mountains, forests, flora, fauna are some features of natural heritage. Natural heritage is unique and irreplaceable and needs to be protected.

\section{Intangible Heritage}

Intangible or living heritage means: "the practices, representations, expressions, knowledge, skills that communities recognize as part of their cultural heritage.

\section{Cultural Heritage}

Cultural heritage include human-made attractions. Cultural heritage attractions were not originally designed to attract tourist. When cultural heritage becomes an attraction in tourism, it is seen not only as "the past", but as the past of a particular cultural community in its present, living context. In this case, tourists not only consume tangible heritage as the main attraction, but they also interact with the community and consume various intangible elements.

\section{II.III. INDIGENOUS TRIBE}

"Indigenous are tribal or semi-tribal populations of a special category who inhabit a particular geographic region and have a specific historical experience." Thus, indigenous people are generally called the native or original inhabitants of an area. (Das, 2001. Pg.19).

Indigenous people are typically distinct in terms of their cultural and social identities. Some key characteristics include:

Self-identification and identification by others as an indigenous cultural group and the display of desire to preserve that cultural identity.

Social, cultural, economic and political traditions distinct from the dominant culture.

Economic systems are oriented toward traditional system of production, not the dominant system

Certain ancestral territories and natural resources in these habitats and territories

(Butler \& Hinch, 2007)

Indigenous people have been perceived to be tourist attractions because of their unique culture and there has been great concern among many communities over the preservation of genuine indigenous culture when it becomes the focus tourism. In recent years, tourists have become more interested in culture, traditions and lifestyles of indigenous tribes. By having direct contacts with indigenous people, tourists are increasingly keen to purchase indigenous arts and crafts as souvenirs and enjoying the cultural activities such as the way of living, and ritual as an integral part of tourist experience.

As the downside of it, commodification, commercialization of culture and following loss of authenticity are some impacts that might occur as the result of exposing indigenous people. (Smith, 2009)

\section{II.IV. IMPACTSF ETHNIC TOURISM}

According to Malhotra (1997), ethnic tourism signifies the tourists' interests in customs of the indigenous and exotic 
peoples. This involves intimate contacts with the "authentic" indigenous culture.

It is important to understand the positive and negative effects of ethnic tourism as it may affect the indigenous people and these are often ignored by the travel trade and policy makers. The following are the positive and negative impacts of ethnic tourism: Positive Impacts

\section{Cultural Revitalization}

Ethnic tourism helps reviving the local people's interest and pride in $\mathrm{t} h$ e i $\mathrm{r}$ cultural traditions and values. Stimulation occurs mainly due to th e outsiders' interests in the local tradition. Thus, the uniqueness and importance of the traditions are brought to the front and lead to ethnic pride and ethnic solidarity. Ethnic revitalization is, therefore, a result of this process. Ethnic tourism also contributes towards strengthening ethnic and political identities.

\section{Economic Benefits}

More employment, higher income, improved standard of living of the

local community etc. are the economic benefits that are accrued from ethnic tourism.

\section{Negative Impacts}

Without care and caution practiced, the signs of negative impacts will

be obvious. The stakeholders which are the researchers, policy- $\mathrm{m}$ a k e r s, government, tourist guides and the members of the local communities itself should watch the phenomenon very carefully in so it does not go out of control. Some of negative impacts of ethnic tourism are:

\section{Commodification of Ethnic and Cultural Products}

Ethnic tourism may influence the local community to reduce their culture only for marketable terms, such as money. In the context of the cultural impact of tourism, commodification may attenuate dignity, value and sanctity of traditional cultures. One simple example is the practice of performing cultural dances and rituals for the tourists to make money. Thus, it can destruct the traditional culture and the people in it.

\section{Staged authenticity}

Staged authenticity is happened when the host community establishes certain authentic elements for the benefit of tourists. Tourists want to $\mathrm{s}$ e e "unspoiled natives". They desire the indigenous ethnic people to b e presented to them in their ethnic dresses, perform their ethnic dances, ceremonies or festivals for them to observe or even to be involved in. It, therefore forces them to act as performers, just to show the tourist their traditional dresses, dances and ceremonies only at the time of their interaction with the tourists, only to satisfy the tourists' demand for "authenticity". Thus, the local people turn into actors for the satisfaction of the tourists. One example of staged authenticity includes traditional handicrafts, which instead of $b$ e i $n g$ handcrafted for their cultural significance, ends up being mass produced for sale to tourists.

\section{The Natives Assume Artificial Behavior}

Imitation of tourist behavior and lifestyle may occur as a result of continuous contact between particular tourists and the 
local community. Local community may adopt tourists' patterns of behavior and moral attitudes and may diminish their originality of the tradition and culture.

\section{II.V. TOURISM DEVELOP- MENT}

According to Goeldner \& Ritchie (2009), a development itself means the modification of environment to certain degree and the application of human, financial, living and also non-living resources to satisfy human needs and improve the quality of human life.

According to Ivanovic (2009), tourism development of a destination cannot be sustained in long term if only the tourist preferences considered and the natural and cultural environments are ignored. Tourism development needs the following concern to be balanced and maintained:

\section{Protection of cultural and natural resources}

Protection of areas and cultural values of indigenous tribe will enhance the tourism development as it is the important essence in harmonizing the cultural resources in an area.

\section{Community interests, and}

Involve both the public and private sector in the development of tourism to help maintaining direction and quality in cultural values which reflect the community interests.

\section{Tourism use.}

By examining the condition of the area's culture and natural resources, stakeholders in this case government can determine the best and worst areas for tourism activities and development. Thus, tourism activities should be assigned to certain areas in which it is appropriate to occur.

Success or failure of tourism development considers the impacts of the relation of demand of tourists and the supply that the culture provides.

Sharma (2004) added, in relation to tourism, there is no universal standard form of tourism development that will be successful in every destination. But how different levels of government in the destination formulate tourism policy may illustrate the regional tourism development plan. Indeed, tourists and local people can help to empower the development. With tourism that has the ability to contribute to the protection and enhancement of traditions, customs and heritage in a destination, the development of a site may also enhance the degree desired development.

It is in the destination that the interaction between hosts and tourists occur and many physical manifestations of the tourism industry are constructed. The appropriateness of tourism development must be considered to further support the destination.

\section{II.VI. DESTINATION}

In order to attract tourists, especially those who seek for cultural experiences, a destination requires a number of pull factors. Pull factors are the desirable attributes or external stimulation of a specific destination or site, the nature, culture, and activities that can be pursued 
there. Richardson \& Fluker (2004, p.67) stated, "Forms of tourism are among pull factors - the destination's offerings to tourists."

Exotic elements of a destination are one of tourism pull factors that are subjected to the perception of the potential tourists. Such attractions are seen different compared with their own regions. Exotic destinations are generally visited only once by the long-distance travelers because usually exotic destinations are located in remote areas. (Jackson \& Hudman, 2003)

A destination is an area where natural attractions and its cultural values are situated to which tourists travel to consume a specific cultural product. An ethnic isolated destination is an example of exotic destinations which involve the importance of local community role in supporting tourism destination development. The processes by which the community members can work together with stakeholders can result positive outcome for them and tourism in their region. One essential activity in the process is the host and guest interaction. (Robinson \& Jamal, 2009)v

\section{II.VII. LEVEL OF ACCEPTANCE}

Desires emerge from the imaginative aspects of human experience and needs emerge soon as prioritization is needed. Community acceptance of tourism depends greatly on the extent to which the attraction reflects the needs and desires of local people and their integration into the industry. Some communities want to engage in tourism development while others perhaps have no desire to do this. It is vital that stakeholders must continually adapt to the community's needs and desire. Number of visitors and economic activity are the closest issues that involve the role of community acceptance and the stakeholders. Some communities and cultures might be able to adjust to a heavy tourist load, whereas others may not. Some might need more economic support while other may not.

Such topics should be discussed within the host community. Although the negative impacts of being an ethnic tourism destination may not show up immediately, they can be a very disruptive force in the long run. (Walle, 2010)

Negative cultural change can be minimized if local people are able to participate and have a role in making decisions about the numbers and types of tourists entering their communities, and at what frequency. $\quad \mathrm{Co} \mathrm{m} \mathrm{m} \mathrm{u} \mathrm{n} \mathrm{t} \mathrm{y}$ participation in the process of tourism development plays a very important role. The essential matter to be addressed is the preservation of the culture that has to be maintained both by the community and also all stakeholders that are involved in the tourism activities.

In many cases, host communities make crafts to be sold. Handicrafts that are made and sold can have good quality-oflife effect for the community. This activity requires participation of the community and can help maintain traditions and preserve cultural heritage. Moreover, their crafts are possibly represented in museums and thus the community can earn great respect as well.

The fact is communities are the basic element of tourism, the successful development of tourism really depends 
upon the goodwill, awareness and acceptance of the local host communities. It is necessary that tourism development in certain area must consider the opinions of the local community whose their involvement is vital in tourism development. Either they are more interested in serving members of own community or generating revenues by catering tourists from the outside world.

The fact that destination attractiveness may be reduced as a result of opening up an indigenous tribe is one consideration that has to be discussed thoroughly within the communities. While tourism earning opportunities may also be affected as well, this matter suggests that tourism development should incorporate the opinions of host communities in order to build community support.

(Talwar, 2006)

\section{METHODOLOGY}

This thesis aims to find out the impacts of opening up of a traditional culture to the development of tourism. It is also to determine how much the Baduy traditional heritage can be exposed to the world. A descriptive research is used to determine how much an opening up of an indigenous tribe could impact the regional tourism development. Descriptive research attemps to describe characteristics of a sample and relationships between phenomena, situations and events. It targets a population and/or a phenomenon and aims to answer the questions " who, what, when, where, and how?"(Robin \& Babbie, 2008).
There will be two types of data used in this thesis, primary data and secondary data. Primary data comprises of both qualitative and quantitative data. Both quantitative and qualitative data have distinctive and important contributions to make the development of new social work knowledge. (Thyer, 20090

The primary qualitative data were gathered from in-depth interviews addressed to Jaro Dainah as the chief of Kanekes Village and government officials. The in-depth interviews with government officials will include personnel of Culture and Tourism Department of Banten Province and officials of Ministry of Culture and Tourism Republic of Indonesia. CPrimary quantitative data were gathered from questionnaires which were addressed to local community of Baduy Tribe and also those who live nearby Kanekes village. Secondary data were gathered from statistic reports, articles, journals, and other literature related to the subject of this thesis. Questionnaires in this study will use Likert scale and are posed in both open ended and close ended questions. The Likert Scale is used to indicate the respondents' level of acceptance of the opening up of The Inner Baduy Tribe.

The data collected will be tabulated and processed in SPSS Program and Microsoft Excel program. The results will be measured in nominal and ordinal scales. The following are the formulas that were used in this research. 


\section{RESULT \& DISCUS- SION}

\section{IV.I. THE BADUY TRIBE}

The Baduy Tribe is located in Kanekes village, Leuwidamar Sub District, Rangkasbitung, Banten which covers an area of 138 hectares. This unique tribe lives in the forests and mountains located at an altitude of 250 meters above sea level, with geographic location of $6^{\circ} 27^{\prime} 27^{\prime \prime}-6^{\circ} 30^{\prime}$ North Latitude and $108^{\circ} 3$ ' 9" - $106^{\circ} 4^{\prime}$ ' "' East longitude. The Baduy Tribe is divided into The Outer Baduy and The Inner Baduy which comprises of 2948 heads of families with a total population of around 11 thousand inhabitants.

Tangtu is a group known as The Inner Baduy. This group lives in the three villages, Cibeo, Cikeusik and Cikertawarna. Their typical clothes are white with white head covering. It is called The Inner Baduy Tribe because the people are still following the customs and cultures inherited from their ancestors. The life in The Inner Baduy is still natural and original so that they are prohibited from adapting and following modern life.

The Panamping group is known as The Outer Baduy. Their typical clothes are black with head covering. Panamping people are found in the western, eastern and northern parts bordering Inner Baduy area such as Cikadu, Kaduketug, Kadukolot, Gajebo, Cisagu. Their customs are more relaxed than the Tangtu's.

The Outer Baduy acts as a guard, filter and a link of information for The Inner Baduy. Although there are differences in freedom from or reduction of the implementation of customary law compared with the Inner Baduy, basically the rules in the Outer Baduy and the Inner Baduy are the same. What differentiates them is how the people respond to external influences. The Outer Baduy Tribe knows more about technology, such as electronic equipments. Moreover, The Outer Baduy Tribe has used some tools such as saws, hammers, and nails to build houses which they were previously prohibited to be used.

The Dangka group lives outside Kanekes village and up until now they live in two villages called Cibengkung and Cihandam. The Dangka people themselves function as a sort of buffer zone of influence from outside.

Although there are differences between The Inner Baduy Tribe and The Outer Baduy Tribe, they live together harmoniously and peacefully. They are very friendly and cultured. They hold a traditional ceremony at the same time such as rice planting and harvest time; they have same belief, culture, and generally the same source of income.

The Baduy Tribe's main source of income is agriculture. Barter trade was conducted in the past but now they use the rupiah. The communities use certain alternating crop pattern in certain period. It is intended that the land that used for cultivation is fertile for the new next cycle. They also receive additional income from selling fruit they harvest from the forest such 
as durian, honey and wild tamarind.

Making handicrafts is also a source of income. Leather bags and handicrafts are made not only by the women but also by men when farming season is over. In fact, most of the weaving activities are carried out by women. Almost every house in Baduy has the tools to weave and these handicrafts are usually for the tourists to buy.

When field work id not too much, the Baduy people also travel to big cities nearby Baduy with a rule that they have to walk and must not use transportation. Generally, they go in small groups consisting of three to five people, visiting the house of their acquaintances that go to Baduy to sell honey and crafts. During the visit they usually get extra money.

The continuity of these traditions includes the active involvements of tourists in honoring, maintaining and preserving them. The Baduy people welcome people to stay at their houses for one or two nights, with the provision that the tourists can comply with applicable customs in Baduy.

\section{IV.II. RESPONDENTS PROFILE}

The profiles of respondents are categorized by gender, age, location and source of income. Each of them is presented in pie charts.

\section{A. Gender}

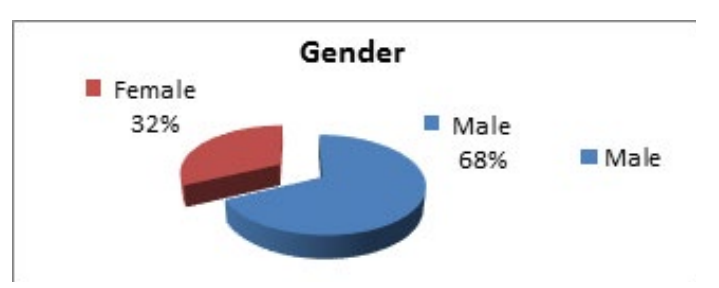

Figure 4.3 Gender Source: Questionnaire
From 81 respondents, 68\% (55 persons) are male and $32 \%$ (26 persons) are female.

\section{B. Age}

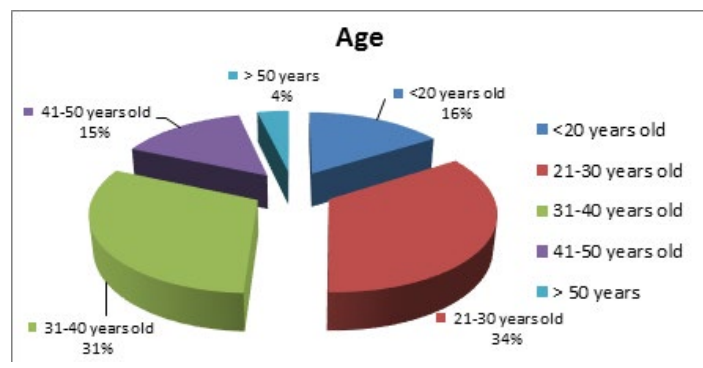

Figure 4.4 Age

Source: Questionnaire

The respondents' ages are between below 20 years old to above 50 years old. The result shows that the highest proportion of $34 \%$ ( 28 persons) are the respondents between the ages of 21-30 years old, followed by second highest of $31 \%$ ( 25 persons) for respondents aged between 31-40 years old. 16\% (13 persons) are under 20 years old, 15\% (12 persons) are between 41-50 years old and only 4\% (3 persons) represents the age above 50 years old.

C. Village Location

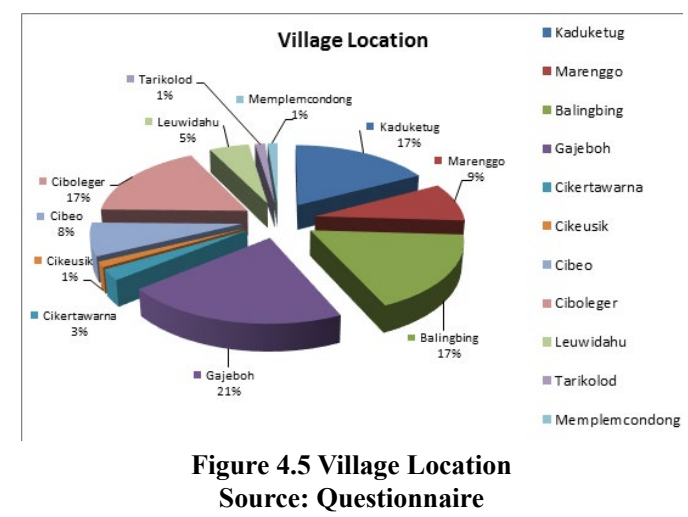

The respondents' locations are dominantly the Gajeboh village that is $21 \%$ (17 persons) of the total number of 
respondents. Respondents from villages of Kaduketug (14 persons), Ciboleger (14 persons) and Balingbing (14 persons) have the same proportion of $17 \%$ each followed by Marenggo village with $9 \%$ (7 persons), Cibeo village with $8 \%$ (6 persons), Leuwidahu village with 5\% (4 persons), Cikertawarna village with 3\% (2 persons) and $1 \%$ each for Cikeusik village (1 person), Tarikolod village (1 person) and Memplemcondong village (1 person).

\section{IV.III. LEVEL OF ACCEPTANCE ANALYSIS}

There are three aspects used to measure the level of acceptance of Baduy Tribe :

Needs And Desires of Local People upon Tourism Development

H0: The needs and desires of local people upon tourism development in Baduy is high

H1: The needs and desires of local people upon tourism development in Baduy is low

The result for one sample T-Test is:

\begin{tabular}{|l|r|}
\hline \multicolumn{2}{|c|}{ Data } \\
\hline Null Hypothesis $\mu=$ & 3 \\
\hline Level of Significance & 0.05 \\
\hline Sample Size & 486 \\
\hline Sample Mean & 2.91563786 \\
\hline Sample Standard Deviation & 0.785882067 \\
\hline
\end{tabular}

\begin{tabular}{|l|r|}
\hline \multicolumn{2}{|c|}{ Intermediate Calculations } \\
\hline Standard Error of the Mean & 0.035648334 \\
\hline Degrees of Freedom & 485 \\
\hline $\boldsymbol{t}$ Test Statistic & $\mathbf{- 2 . 3 6 6 5 0 9 9 9 7}$ \\
\hline
\end{tabular}

\begin{tabular}{|l|c|}
\hline \multicolumn{2}{|c|}{ Lower-Tail Test } \\
\hline Lower Critical Value & -1.648001465 \\
\hline$p$-Value & 0.009174334 \\
\hline \multicolumn{2}{|c|}{ Reject the null hypothesis } \\
\hline
\end{tabular}

\begin{tabular}{|l|r|}
\hline Confidence Interval & \\
\hline Interval Lower Limit & 2.85 \\
\hline Interval Upper Limit & 2.99 \\
\hline
\end{tabular}

Table 4.2 T-Test and Confidence Level Result on Needs and Desires of Local People upon Tourism Development in Baduy Source: PHStat2
Interpretation:

The $\mathrm{t}$ value gained on whether the needs and desires of local people upon tourism development in Baduy is -2.366 .

That means: $-2.366<<-1.66>$ reject the $\mathrm{H} 0$.

It is concluded that the needs and desires of local people on tourism development in Baduy is low.

2. Community Tourism Participation of Local People on the Tourism Activities In Baduy

H0: Community tourism participation of local people on the tourism activities in Baduy is high

H1: Community tourism participation of local people on the tourism activities in Baduy is low

The result for one sample T-Test is:

\begin{tabular}{|l|r|}
\hline \multicolumn{2}{|c|}{ Data } \\
\hline Null Hypothesis $\mu=$ & 3 \\
\hline Level of Significance & 0.05 \\
\hline Sample Size & 566 \\
\hline Sample Mean & 3.077738516 \\
\hline Sample Standard Deviation & 0.771826366 \\
\hline
\end{tabular}

\begin{tabular}{|l|r|}
\hline \multicolumn{2}{|c|}{ Intermediate Calculations } \\
\hline Standard Error of the Mean & 0.032442282 \\
\hline Degrees of Freedom & 565 \\
\hline $\boldsymbol{t}$ Test Statistic & $\mathbf{2 . 3 9 6 2 0 9 8 6}$ \\
\hline
\end{tabular}

\begin{tabular}{|l|c|}
\hline \multicolumn{2}{|c|}{ Lower-Tail Test } \\
\hline Lower Critical Value & -1.647555018 \\
\hline$p$-Value & 0.991555121 \\
\hline \multicolumn{2}{|c|}{ Do not reject the null hypothesis } \\
\hline
\end{tabular}

\begin{tabular}{|l|r|}
\hline Confidence Interval & \\
\hline Interval Lower Limit & 3.01 \\
\hline Interval Upper Limit & 3.14 \\
\hline
\end{tabular}

Table 4.3 T-Test and Confidence Level Result on Community Tourism Participation of Local People on the Tourism Activities in Baduy Source: PHStat2 
Interpretation:

The $t$ value gained on whether the needs and desires of local people upon tourism development in Baduy is 2.396.

That means: $2.396-1.66$ accept the Ho.

It is concluded that the community tourism participation of local people on the tourism activities in Baduy is high

\section{The Opinions of Local People about the Opening Up of The Inner Baduy Tribe.}

H0: The opinions of local people about the opening up of the Inner Baduy

Tribe are high

H1: The opinions of local people about the opening up of the Inner Baduy Tribe are low

The result for one sample T-Test is:

\begin{tabular}{|l|r|}
\hline \multicolumn{2}{|c|}{ Data } \\
\hline Null Hypothesis $\mu=$ & 3 \\
\hline Level of Significance & 0.05 \\
\hline Sample Size & 810 \\
\hline Sample Mean & 2.771604938 \\
\hline Sample Standard Deviation & 0.939943791 \\
\hline
\end{tabular}

\begin{tabular}{|l|r|}
\hline \multicolumn{2}{|c|}{ Intermediate Calculations } \\
\hline Standard Error of the Mean & 0.033026258 \\
\hline Degrees of Freedom & 809 \\
\hline $\boldsymbol{t}$ Test Statistic & $\mathbf{- 6 . 9 1 5 5 5 9 7 1}$ \\
\hline
\end{tabular}

\begin{tabular}{|l|r|}
\hline \multicolumn{2}{|c|}{ Lower-Tail Test } \\
\hline Lower Critical Value & -1.646739321 \\
\hline$p$-Value & $4.73269 \mathrm{E}-12$ \\
\hline \multicolumn{2}{|c|}{ Reject the null hypothesis } \\
\hline
\end{tabular}

\begin{tabular}{|l|r|}
\hline Confidence Interval & \\
\hline Interval Lower Limit & 2.71 \\
\hline Interval Upper Limit & 2.84 \\
\hline
\end{tabular}

Table 4.4 T-Test and Confidence Level Result on Opinions of Local People About The Opening Up of The Inner Baduy Tribe. Source: PHStat2
Interpretation:

The $t$ value gained on whether the needs and desires of local people upon tourism development in Baduy is -6.915 .

That means: $-6.915<-1.66>$ reject the $\mathrm{H} 0$.

It is concluded that the opinions of local people about the opening up of the Inner Baduy Tribe are low.

\section{IV. Hypothesis Analysis \\ Hypothesis \#1:}

H0: The Baduy Tribe accepts the opening up of the Inner Baduy.

H1: The Baduy Tribe do not accept the opening up of the Inner Baduy.

The result for one sample T-Test is:

\begin{tabular}{|l|r|}
\hline \multicolumn{2}{|c|}{ Data } \\
\hline Null Hypothesis $\quad \Xi$ & 3 \\
\hline Level of Significance & 0.05 \\
\hline Sample Size & 1781 \\
\hline Sample Mean & 2.913531724 \\
\hline Sample Standard Deviation & $\mathbf{0 . 8 6 7 8 6 7 0 3 7}$ \\
\hline
\end{tabular}

\begin{tabular}{|l|r|}
\hline \multicolumn{2}{|c|}{ Intermediate Calculations } \\
\hline Standard Error of the Mean 0 & .020564646 \\
\hline Degrees of Freedom 1 & 780 \\
\hline & - \\
$\boldsymbol{t}$ Test Statistic & $\mathbf{4 . 2 0 4 7 0 5 3 5 1}$ \\
\hline
\end{tabular}

\begin{tabular}{|l|r|}
\hline \multicolumn{1}{|c|}{ Lower-Tail Test } & \\
\hline & - \\
Lower Critical Value & 1.645710126 \\
\hline$p$-Value & $1.37201 \mathrm{E}-05$ \\
\hline Reject the null hypothesis & \\
\hline
\end{tabular}

\begin{tabular}{|l|r|}
\hline Confidence Interval & \\
\hline Interval Lower Limit & $\mathbf{2 . 8 6}$ \\
\hline Interval Upper Limit & $\mathbf{2 . 9 4}$ \\
\hline
\end{tabular}

Table 4.5 T-Test and Confidence Level Result on Level of Acceptance of Local People about the Opening up of The Inner Baduy Tribe. Source: PHStat2 
Interpretation:

The $t$ value gained on level of acceptance of the Local People of Baduy on the Opening up of The Inner Baduy is - 4.204

That means: $-4.204<-1.66>$ reject the Ho.

It is concluded that the Baduy Tribe do not accept the opening up of the Inner Baduy.

\section{IV.V. Result of Interview}

The time frame for in-depth interview was undertaken between May 62011 and May 222011 (17 days). Interviews were conducted in order to gain in depth information on the possibility of opening up an indigenous tribe to public and its impacts on regional tourism development. Interviews were directed to Department of Culture and Tourism of Banten Province, Representatives of Baduy including the head of the village, head of development and society spokesman. Some insights are also gained from a journalist who has adequate information about the related subject. Total interviewees are 6 and were interviewed in Baduy, Serang and Jakarta.

\section{TOURISM IN BANTEN}

The current tourism development in Banten is positive. Number of tourists keeps increasing due to extensive promotion, but it is not yet at the optimum level. It still needs many improvements; one of which is the improvement of the road condition, from the district to the sub district where the Baduy Tribe is located. Further, proactive involvement and coordination of public sectors with tourism stakeholders need to be developed.

The Baduy Tribe has a unique culture, making it a famous tribe in Indonesia's and international tourism. The Baduy area is considered as a conservation site under the protection of the government. They have visitors, the number of which increases although slow.

Majority are domestic tourists visiting mostly the Outer Baduy.The inner Baduy allows visitors to enter the region as long as they respect the tribal rules and regulations. Another factor that affects the slow development of tourism is the access to Baduy region because of poor condition of roads between Rangkasbitung to Ciboleger where the Baduy people live. Also the walk within Inner Baduy villages is a challenge for any visitors as is at least $12 \mathrm{~km}$ of rough walk from the entering point to the first village. The low knowledge on tourism from the community is also a factor that causes slow development in tourism.

(Source: Interviews with Department of Culture and Tourism of Banten Province, The Baduy Tribe heads of community, Journalist)

\section{POSSIBILITY OF OPENING UP THE INNER BADUY}

\section{Affirmation}

Baduy has a great potential to attract tourists to Banten, The unique way of life of inner Baduy is the factor that draws great curiosity of many travelers. But it is to Baduy people to decide whether they want to be exposed or not to mass visits because what is important for them Baduy people is the preservation is to preserve their cultural and traditional way of life and protect their heritage from outside influence. 
Basically the Inner Baduy is open for visit as long as tourists obey the rules inside the Inner Baduy area and the local community can take control of tourists' behavior. The possibility to visit is also conditioned by regulation of prohibiting 'white people' to enter inner baduy area and, during the months of 'Kawalu' Baduy area is closed for any visit. But the opening up of the Inner Baduy Tribe to a wider market for at present is not a priority and the concern to Baduy community.

\section{Denial}

Customarily, the Inner Baduy may not be opened to outside visitors. If it is officially opened to public, it can lead to uncontrollable behavior of tourists. This leads to damage to environments and influence the authenticity of their cultural heritage.

The Baduy community treasure highly their culture and never defied any cultural rules and regulations.

There is a council to remind the Baduy people to stay wise and simple. In the Inner Baduy, this council consists of seven chiefs members who are the elders from the villages called "Jaro 7" who have the responsibility and authority to maintain the authenticity of their heritage.

Natural environment is important for the Baduy people because their lives depends on the natural resources.

(Source: Department of Culture and Tourism of Banten Province, The Baduy Tribe heads of community, Journalist)

\section{IMPACTS OF OPENING UP THE INNER BADUY}

\section{Positive:}

\section{To Regional Tourism Development:}

Commercialism that stimulate the increase of number of tourists.

The improvement of tourism development can support a better economy and image for the region.

Tourism development can support the improvement of infrastructure and trigger the emergence of businesses.

\section{To Community:}

Baduy people will get more economic benefits from the handicrafts they sell

\section{Negative:}

\section{To Regional Tourism Development:}

The opening up of Inner Baduy to tourism may cause acculturation and environmental damages. This impact the authenticity of ethnic culture which lessens the interests of tourists and therefore causing less number of tourists coming to Banten.

\section{To Community:}

Acculturation between modern and traditional way of life that degrade the authenticity of the culture

Environmental damage will happen as a result of uncontrollable behavior of tourists

Degradation of language (the using of slang words). This could endanger the cultural continuity

Change of attitude of the Baduy people as a consequence of contacts with outside people. 
(Source: Department of Culture and Tourism of Banten Province, The Baduy Tribe heads of community, Journalist)

\section{CONCLUSION}

The Baduy Tribe is a cultured and friendly indigenous people living harmoniously in the middle of natural environment and far from the civilization. It is a tribe that is attached and loyal to their heritage. Generally the Baduy people have only basic education taught by their family.

Possibility and the level of acceptance of opening up the Inner Baduy as a tourism destination:

Three elements are used to justify the level of acceptance of the Baduy people to the opening up of the Inner Baduy are needs and desires, community tourism participation, and opinions out of these three, two showed rejections (needs and desires and opinions on opening up the Inner Baduy). This is strengthened by the result of the interviews that tribe rules and regulations do not allow the Inner Baduy to be opened up.

The Inner Baduy is actually already visited by tourists but in limited amount of people. They are conditioned to abide the regulations when visiting the area. Further, there is also prohibition for white people to enter the Inner Baduy.

Impacts on the opening up the Inner Baduy to tourism development:

According to Wahab \& Pigram (1997), cultural carrying capacity is needed to assure that certain number of visitors do not damage the cultural resources that local people have.

This is proven by the disadvantages that impact the host community if the Inner Baduy is opened up to tourism market. It could cause culture acculturation, a deterioration of morality, environmental damages, and also the decreased quality of local people's language. For the regional development, the opening up of the Inner Baduy can bring advantages such as improvements of infrastructures and economic benefits.

To conclude, the Inner Baduy is unofficially opened for visits from the tourists but the policy to open it up to mass market depends entirely on the decision of the host

\section{REFERENCES}

Books and Journal

Aczel, A.D., \& Sounderpandian, J. Complete Business Statistics. New York: McGraw-Hill Publication Company, 2002.

Bhatia, A.K. The Business of Tourism: Concepts and Strategies. New Delhi: Sterling Publishers Private Limited, 2002.

Bryman, A., \& Bell, E. Business Research Methods. Oxford: Oxford University Press, 2007.

Burns,C., \& Bush, R.F. Marketing Research. New Jersey: Pearson International, 2006.

Butler, R., \& Hinch, T. Tourism and Indigenous Peoples: Issues and Implications. U.K: ButterworthHeinemann, 2007

Carrier, J.G. Tourism, Power and Culture: Anthropological Insights. U.K: Channel 
View Publications, 2010.

Cerroni-Long, E.L. Anthropological Theory in North America. United States: Greenwood Publishing Group, 1999.

Das, J.K. Human Rights and Indigenous Peoples. APH Publishing, 2001

Goeldner, C.R. \& Ritchie, J. R. B. Tourism: Principles, Practices, Philosophies. Canada: John Wiley and Sons, 2006.

Gravetter, F.J., Forzano., \& Lori-Ann, B. Research Methods for the Behavioral Sciences. USA: Cengage Learning, 2008.

Hall, C. Michael., \& Lew, Alan A. Understanding and Managing Tourism Impacts: An Integrated Approach. USA: Taylor \& Francis, 2009.

Hollinshead, Keith, Encounters in Tourism. In VNR's encyclopedia for Hospitality and Tourism. edited by Mahmoood A.Khan, Michael D.Olsen, Turgut Var (Van Nostrand Reinhold). New York: John Wiley \& Sons, 1993.

Ivanovic, Milena. Cultural Tourism. Cape Town: Juta and Company Limited, 2009.

Jackson, R.H., \& Hudman, L.E. Geography of Travel And Tourism. New York: Delmar Cengage Learning, 2003.

Jafari,Jafar. Encyclopedia of Tourism. London: Routledge, 2003.

Jamal, Tazim., \& Robinson, M. The SAGE Handbook of Tourism Studies. London: SAGE Publications Ltd, 2009.

Johnson, B., Christensen, L. Educational Research: Quantitative, Qualitative, and Mixed Approaches. London: SAGE Publications Ltd, 2010.

Kurnia, A., \& Sihabudin, A. Saatnya Baduy Bicara. Rawamangun: Bumi Aksara, 2010
Leslie, David., \& Sigala, Marianna. International Cultural Tourism: Management, Implications And Cases. Oxford: Butterworth-Heinemann, 2005.

Leuterio, Florida C. Introduction to Tourism, 1st edition. Manila: Rex Book Store, 2007.

Malhotra, R.K. Encyclopaedia of Hotel Management And Tourism, Volume 1. New Delhi: Anmol Publications PVT. LTD, 1997.

Nuryanti, Wiendu. The Role of Heritage Tourism in Community Planning and Development. Yogyakarta: Gadjah Mada University Press, 2009.

OECD. Tourism Trends and Policies 2010. France: OECD, 2010.

Oh, Haemoon., \& Pizam, Abraham . Handbook of Hospitality Marketing Management.

Oxford: Butterworth-Heinemann, 2008.

Reynish, Khunou., Tseane, Pawson, \& Ivanovic. Fresh Perspectives: Tourism Development 1. South Africa: Pearson, 2009.

Richardson, J.I., \& Fluker, M. Understanding and Managing Tourism. Australia: Pearson Education Australia, 2004.

Sharma, K.K. Tourism and Socio-Cultural Development.1st Edition. New Delhi: Sarup \& Sons, 2004.

Sharma, K.K. Tourism and Development. New Delhi: Sarup \& Sons, 2005.

Smith, M., MacLeod, Nicola., Robertson, M.H. Key Concepts in Tourist Studies. Singapore: SAGE Publications Ltd, 2009.

Talwar, Prakash. Travel And Tourism Management: (In 4 Volumes). India: ISHA Books, 2006. 
Thyer, Bruce. The Handbook of Social Work Research Methods. California: SAGE Publications, 2009.

Van den Berghe, Pierre L. Cultural Tourism. In VNR'S Encyclopedia of Hospitality and Tourism, edited by Mahmoood A.Khan, Michael D.Olsen, Turgut Var (Van Nostrand Reinhold). New York: John Wiley \& Sons, 1993.
Wahab, Saleh., \& Pigram, John. J. Tourism, Development and Growth: The Challenge of Sustainability. New York: Routledge, 1997.

Walle, A.H. The Equitable Cultural Tourism Handbook. U.S.A: Information Age Publishing, 2010. 